\title{
Maternal Outcome in Emergency Peripartum Hysterectomy: Minimizing the Risks
}

\author{
Shumaila Zia, Muhammad Rafique, Aisha Rizwan, Tamkin Khan, Ali Al-Shamrani
}

\author{
ABSTRACT \\ Objective: To study the incidence, causes and maternal \\ outcome in emergency peripartum hysterectomy.
}

\begin{abstract}
Materials and methods: Retrospective, descriptive study of emergency peripartum hysterectomy by analyzing the labor records of patients undergoing the procedure in the past 5 years.
\end{abstract}

Results: There were 57 emergency hysterectomies among the 28940 deliveries, over the past 5 years. The incidence of EPH was 1.97 per 1000 deliveries. The mean age of the patients was $35.03 \pm 5.9$ (range: $21-47$ ) years. Mean parity was $4.8 \pm 2.8$ (range: $0-13$ ). Of 57 patients, $50(87.7 \%)$ patients had previous history of cesarean section (CS). The main indications for hysterectomy were placental abnormalities $63.1 \%$ $(O R=1.54 ; 95 \% \mathrm{Cl}=9.5-13.34$, $\mathrm{p}$-value $<0.001)$ and uterine atony $24.5 \%(\mathrm{OR}=1.42 ; 95 \% \mathrm{Cl}=7.43-15.43$, $\mathrm{p}$-value $<0.001)$. Subtotal hysterectomy was performed in majority $50(87.7 \%)$ of the cases. Bladder injury was the significant intraoperative complication in $17(30 \%)$ cases $(\mathrm{OR}=1.87 ; 95 \% \mathrm{Cl}=9.45$ 18.97, p-value $<0.001$ ) with no residual damage. Infections were the commonest complication seen in $15(26 \%)$ patients postoperatively. The maternal mortality occurred in 2 (3.5\%) patients.

Conclusion: Emergency peripartum hysterectomy, though uncommon, remains a challenging but life saving procedure in obstetrics. Its indications in modern obstetrics are changing and still emerging. Abnormal placentation, previous CS, multiparity are important risk factors. Antenatal diagnosis of low lying and adherent placenta, minimizing the CS rate, proper and timely management of third stage of labor and emergency preparedness are imperative to minimize the chances of emergency peripartum hysterectomy and improving the outcome.

Keywords: Emergency peripartum hysterectomy, P ostpartum hemorrhage, Uterine rupture, Abnormal placentation, Uterine atony, Previous cesarean section, Near miss events.

How to cite this article: Zia S, R afique M, Rizwan A, Khan T, Al-Shamrani A. Maternal Outcome in Emergency Peripartum Hysterectomy: Minimizing the Risks. J South Asian Feder Obst Gynae 2013;5(3):91-95.

Source of support: Nil

Conflict of interest: None

\section{INTRODUCTION}

Emergency peripartum hysterectomy (EPH) is usually performed life-threatening and intractable obstetric hemorrhage and may therefore be considered a near-miss event. ${ }^{1} \mathrm{EPH}$ is defined as a hysterectomy performed at the time of delivery or in the immediate postpartum period. The risk factors, causes, maternal outcome of the procedure differ dramatically in different parts of the world and al so within the same regions of the world. Several studies from different regions of Kingdom of Saudi A rabia (KSA) have reported different frequencies, indications and maternal outcome associated with EPH. The variation is because of differences in the availability of antenatal care, intranatal monitoring, obstetric and surgical skill, blood transfusion facilities and an efficient transport system. It is a procedure which if performed carefully and at the right time reduces maternal mortality. The decision to perform an EPH is a challenging and difficult decision at times as it puts an end to the obstetric career of the woman. This is especially so in areas where the sociocultural compul sions tend to associate fertility with feminity and a woman's ability to produce children are considered as her biggest asset. Recent reports show that abnormal placental adherents and placenta previa are emerging as the major indications for obstetric hysterectomy as opposed to rupture of uterus and sepsis. Increase in the number of cesarean deliveries over the past two decades maybe one of the causes for an increase in placenta related complications. ${ }^{2}$ EPH is associated with severe blood loss, intraoperative complications, significant postoperative morbidity and maternal mortality. A very high incidence of maternal morbidity and mortality is reported from developing countries. ${ }^{3}$ In countries like KSA, where women tend to delay the consent for hysterectomy because of sociocultural factors, the operation is carried out when the condition of the patient is in a critical condition increasing her risks from anesthesia and surgery.

\section{OBJECTIVES}

1. To record the incidence and causes for emergency peripartum hysterectomy (EPH) in modern obstetric practice in KSA.

2. To analyze the outcome of the procedure in terms of morbidity and mortality and identify the risk factors determining the outcome of these cases.

3. To suggest strategies for decreasing the incidence and improving the maternal outcome.

\section{MATERIALS AND METHODS}

This was a retrospective, descriptive analysis of 57 cases of EPH performed at A bha General Hospital A bha, KSA from J anuary 2008 to December 2012. A ll cases who underwent an emergency hysterectomy for life-threatening postpartum hemorrhage after 24 weeks' gestation within 24 hours of delivery were analyzed. Information regarding maternal parameters including age, parity, previous CS, estimated blood loss, blood transfusion, the indications for EPH and associated maternal morbidity and mortality was collected. 
Details of intraoperative complications was obtained from the operation notes. Total preoperative, intraoperative and postoperative blood loss and blood transfusions were calculated. M aternal mortality, preoperative and postoperative complications and morbidity were used as indicators of maternal outcome. No formal institutional policy exists regarding the indication for the performance of the emergency hysterectomy, or its timing except the protocol that all decisions to perform a hysterectomy and the operation itself were performed by the senior most consultant.

The data was analyzed by using SPSS version 17. Q ualitative variables were presented as frequencies and percentages. A 95\% confidence interval for indications and complications was estimated to compare our results with other studies. Quantitative variables were presented as mean \pm standard deviation (SD).

\section{RESULTS}

D uring the period of study a total of 28940 deliveries including 8640 CS (42\%) and 20300 (58\%) vaginal deliveries were conducted. Out of these 57 patients underwent EPH. The incidence of EPH was 1.97 per 1000 deliveries. It was higher after CS $(0.6 \%)$ than after vaginal deliveries $(0.28 \%)$.

Table 1: R elationship between age and parity of women

\begin{tabular}{lccccccccr}
\hline \multicolumn{1}{l}{ Age (years) } \\
\hline & 0 & 1 & 2 & 3 & 4 & 5 & 6 & $>6$ & Total (\%) \\
\hline 20 to 25 & 1 & 2 & - & - & - & 1 & - & - & $4(7)$ \\
25 to 30 & 1 & 2 & 2 & 2 & 1 & 2 & 1 & - & $11(19.3)$ \\
30 to 35 & - & 1 & 4 & 4 & 3 & 3 & 1 & - & $16(28)$ \\
35 to 40 & - & - & - & 1 & - & 7 & 4 & 5 & $17(30)$ \\
40 to 45 & - & - & - & - & - & - & 1 & 6 & $7(12)$ \\
$>45$ & - & - & - & - & - & - & - & 2 & $2(3.5)$ \\
\hline Total (\%) & 2 & 5 & 6 & 7 & 4 & 13 & 7 & 13 & 57 \\
& (3.5) & (9) & $(10.5)$ & $(12)$ & (7) & $(22.8)$ & $(12)$ & $(22.8)$ \\
\hline
\end{tabular}

\begin{tabular}{|c|c|c|c|}
\hline \multirow{2}{*}{$\begin{array}{l}\text { Indications } \\
\begin{array}{l}\text { 1. placental } \\
\text { abnormalities }\end{array}\end{array}$} & \multicolumn{2}{|c|}{$\mathrm{n}=57$ Percentage } & \multirow{2}{*}{$\begin{array}{l}\text { p-value } \\
0.0001 \\
(\mathrm{OR}=1.54,95 \% \\
\mathrm{Cl}=9.45-13.34)\end{array}$} \\
\hline & 36 & 63.1 & \\
\hline Placenta previa-IV & 16 & 44.4 & 0.258 \\
\hline Placenta accreta & 8 & 22.2 & 0.456 \\
\hline Placenta percreta & 5 & 13.9 & 0.369 \\
\hline Morbid adherent & 4 & 11.1 & 0.247 \\
\hline Placenta increta & 3 & 8.3 & 0.125 \\
\hline 2. Uterine atony & 14 & 24.5 & $\begin{array}{l}0.0001 \\
(\mathrm{OR}=1.42,95 \% \\
\mathrm{Cl}=7.43-15.43)\end{array}$ \\
\hline Obstructed labor & 4 & 28.6 & 0.235 \\
\hline Chorioamnionitis & 4 & 28.6 & 0.235 \\
\hline Severe anemia & 2 & 14.3 & 0.125 \\
\hline Twin pregnancy & 1 & 7.1 & 0.102 \\
\hline 3. Placental abruption & 3 & 5.2 & 0.252 \\
\hline 4. Scar dehiscence & 2 & 3.5 & 0.525 \\
\hline 5. Uterine rupture & 2 & 3.5 & 0.369 \\
\hline
\end{tabular}

$\mathrm{CI}$ : Confidence interval; OR: Odd ratio
The mean age of the patients was $35.03 \pm 5.9$ (range: 21-47) years.

M ean parity was $4.8 \pm 2.8$ (range: 0 -13). Table 1 shows relationship between age and parity. The mean gestational age at time of delivery was $35.14 \pm 5.3$ (range: 17-40) weeks.

The indication of all hysterectomies was uncontrolled postpartum hemorrhage, 50 (87.7\%) followed CS and 7 (12.2\%) after vaginal deliveries. Of 57 patients, $50(87.7 \%)$ had previous history of CS. The mean number of previous CS was $2.4 \pm 1.6$ (range: 1- 6). Placental abnormalities 63.1\% (placenta previa type IV and morbidly adherent placenta) and uterine atony $24.5 \%$ were the most common causes of EPH (Table 2).

Majority $50(87.7 \%)$ of the patients had subtotal while 7 $(12.2 \%)$ had total hysterectomy. All the hysterectomies were performed by senior most consultant obstetrician on duty. Type and frequency of intraoperative and postoperative complications are given in Table 3. Eight (14\%) patients had to be re-explored due to clinical evidence of internal bleeding, five cases whilst in recovery room and three patients 12 hours postoperative. Out of the 57 cases, $2(3.5 \%)$ were uterine artery ligation failures, 31 (54.3\%) were bleeding after uterine packing and in $20(35 \%)$ cases B-Lynch suture failed to control PPH resulting in decision for EPH. Estimated blood loss ranged 1000 to $8000 \mathrm{ml}$ with a mean $2591 \pm 1143 \mathrm{ml}$. All patients were transfused with blood products. Number of blood transfusions required ranged from 2 to 18 units depending upon blood loss and preoperative condition of the patient. A mean of 6 units of red cell concentrate, 4 units of fresh frozen plasma and 5 units of platel ets was transfused to these women. In total, these 57 women received 337 units of RBC, 111 units of FFP and 20 units of platel ets. There were $2(3.5 \%)$ maternal deaths, one patient died soon after surgery from irreversible shock and the other died because of pulmonary embolism. Two patients recovered from near- miss death. One was revived after two

\begin{tabular}{lccl}
\multicolumn{4}{c}{ Table 3: Complications of emergency peripartum } \\
hysterectomy, $\mathrm{n}=57$ patients
\end{tabular}

Cl: Confidence interval; OR: Odd ratio; DIC: Disseminated intravascular coagulation; UTI: U rinary tract infection; RTI: Respiratory tract infection 
episodes of cardiac arrest and another one from massive pulmonary embolism and DIC. They were shifted to higher centers for ICU services. The mean duration of hospital stay for the surviving women was $14.5 \pm 7.2$ (range: 6-42) days. The longest stay of 42 days was in a patient who developed bladder injury intraoperatively and broad ligament hematoma following surgery. The main risk factors observed in this study included age $>35$ years in $(45.6 \%)$, multiparity in $(65 \%)$, placenta previa and related abnormal ities in (63\%) and history of previous CS in $(87.7 \%)$ patients. As the number of risk factors increased, so did the risk of EPH.

Table 4 shows a comparison of other studies with ours in terms of incidence, indications, complications and maternal mortality associated with the procedure.

\section{DISCUSSION}

E mergency peripartum hysterectomy, though uncommon, remains a potentially life-saving procedure. The frequency of EPH in the present study is 1.9 per 1000 deliveries which is different from those quoted from other regions of Saudi A rabia., ${ }^{4}$ The highest rates of 2.5 to 5.4 per 1000 have been reported in A sia and A frica and lowest of 0.17 to 1.9 per 1000 deliveries in N orth A merica, Central Europe and Middle East. ${ }^{6-8}$ Our EPH incidence is similar to that reported from developed countries as a result of good antenatal services, availability of efficient transport and blood bank services, a very high accountability and reluctance on the part of the patient to give a consent for hysterectomy.

Contemporary data suggest that the vast majority of EPH occurs emergently in the setting of an invasive or abnormally located placentation or uterine atony. ${ }^{7}$ The current study corroborates literature. The most frequent indication for EPH in the present study was abnormal placentation in $63 \%$ followed by uterine atony in $24.5 \%$ cases. These findings are consistent with most frequent indications reported from developed countries. ${ }^{1,9}$ The indications of $\mathrm{EPH}$ in various studies have been compared with those of ours in Table 4. It is reported in literature, ${ }^{10}$ that the incidence of EPH due to uterine atony has declined from 42 to $29.2 \%$ and incidence due to abnormal placentation has increased from 25.6 to $41.7 \%$. This may be due to increased CS rate, resulting in abnormal placentation and invasion anomalies on one hand and better treatment of uterine atony with evidence based protocols and a better armamentarium of uterotonic drugs available to us. ${ }^{5}$ This trend was reflected from our study also.

$M$ ajority of the patients who underwent EPH were in age group 30 to 40 years (60\%) and were multipara (65\%). Similar trend was observed by R abiu et al ${ }^{11}$ and Tebeu et al ${ }^{12} \mathrm{~A}$ Ithough the majority of the patients were multipara but we also found two primigravida women. This finding was in agreement with others. ${ }^{13}$ One of the primis had uterine atony because of prolonged obstructed labor and other was a case of PPH without any identifiable cause. This could mean that primigravidae are not immune to $\mathrm{EPH}$ and risk should not be underestimated in this group of women as well. The presence of placenta previa, placenta accreta, previous CS and multiparity were found as main risk factor in this series as has also been described by other researchers. ${ }^{7,14}$ We found that a very high number of women undergoing EPH were cases of previous cesarean section $(42 \%)$. This ia a major risk factor for placenta previa and morbid adhesions of placenta requiring peripartum hysterectomy. In order to minimize the incidence of EPH we need to cut down the CS rate. The risk of litigations and medicolegal issues resulting in obstetrician distress and psychological stress to expatriate surgeons maybe partly responsible for this increase in the number of first and repeat CS. The practice of having large families also increases the number of repeat CS. These underlying causes need to be addressed.

This study has also revealed that subtotal hysterectomy was performed more frequently $(87.7 \%)$ than total abdominal

\begin{tabular}{|c|c|c|c|c|}
\hline Study & Incidence/1000 & Indications & Mortality & Morbidity \\
\hline $\begin{array}{l}\text { Mesleh et al } \\
\text { 1998, KSA }\end{array}$ & 0.3 & Placenta previa (75\%) & 0 & $69 \%$ \\
\hline $\begin{array}{l}\text { Afaf et al } \\
2000, \text { KSA }\end{array}$ & 0.3 & $\begin{array}{l}\text { Uterine injury ( } 40 \%) \\
\text { Placenta previa (36\%) }\end{array}$ & $8 \%$ & $48 \%$ \\
\hline $\begin{array}{l}\text { Knight et al }{ }^{1} \\
\text { 2007, UK }\end{array}$ & & $\begin{array}{l}\text { Uterine rupture }(53 \%) \\
\text { Placenta previa }(38 \%)\end{array}$ & $0.6 \%$ & $17 \%$ \\
\hline $\begin{array}{l}\text { Roethlisberger } \\
2010, \text { Viana }^{23}\end{array}$ & 1.39 & $\begin{array}{l}\text { Abnormal adherent } \\
\text { placenta }\end{array}$ & 0 & \\
\hline $\begin{array}{l}\text { Chibber et al }{ }^{18} \\
2011, \text { Kuwait }\end{array}$ & 0.39 & $\begin{array}{l}\text { Atonic PPH }(46 \%) \\
\text { Placenta previa }(34 \%)\end{array}$ & $3.6 \%$ & $49 \%$ \\
\hline $\begin{array}{l}\text { Cristopoulos }{ }^{24} \text { et al } \\
2011, \text { Greece }\end{array}$ & 0.92 & Placenta accreta $(73 \%)$ & $6.6 \%$ & $47 \%$ \\
\hline $\begin{array}{l}\text { Awan et al }{ }^{17} \\
2011, \text { Sydney }\end{array}$ & 0.85 & $\begin{array}{l}\text { Morbid adherent } \\
\text { placenta }(55 \%)\end{array}$ & $3 \%$ & \\
\hline Topisiz et $\mathrm{al}^{25}$ & 0.36 & Uterine atony $(43 \%)$ & & \\
\hline 2012, Turkey & & Placenta accreta $(40 \%)$ & $6.6 \%$ & \\
\hline $\begin{array}{l}\text { Obiechina et al }{ }^{13} \\
2012, \text { Nigeria }\end{array}$ & 6.2 & Placenta previa (48\%) & $31 \%$ & \\
\hline $\begin{array}{l}\text { Present study } \\
2013, \text { KSA }\end{array}$ & 1.97 & $\begin{array}{l}\text { Placental abnormalities (63\%) } \\
\text { Uterine atony }(25 \%)\end{array}$ & $3.5 \%$ & $66 \%$ \\
\hline
\end{tabular}

PPH: Postpartum hemorrhage 
hysterectomy. Comparable incidences have been quoted in recent reports all over the world ${ }^{2,11,15}$ However, a large study from UK reported a rate of total hysterectomy as high as $47 \%{ }^{1}$ Though, the indication for hysterectomy in our study was mainly related to placenta previa but rate of total hysterectomy vs subtotal was not very high unlike the UK study who explained the high rate of total hysterectomy in spite of the unstable maternal condition requiring a simpler and speedy procedure to the fact that in majority of the cases the indication was placental. Studies and guidelines have suggested that subtotal hysterectomy is a preferable operation because of lower degree of hemorrhage and speed of surgery. ${ }^{16}$

Almost half of women suffered damage to adjacent organs like the bladder, ureters, broad ligament and $14 \%$ required relaparotomy to control hemorrhage or repair organ damage. The maternal mortality in the present series was found $3.5 \%$ which is broadly similar to the reports from developed countries. ${ }^{17} \mathrm{Th}$ his figure is much lower than a report from Riyadh KSA but comparable to observations from Kawait. ${ }^{18}$ Improved and efficient blood banking services, antibiotics, safe anesthesia and advances in surgical technique are the major factors contributing to better outcomes and reduced maternal mortality rates. The present study confirms the earlier observations that $\mathrm{EPH}$ is associated with high maternal morbidity. ${ }^{19,20} \mathrm{~B}$ roadly in line with another report from KSA, ${ }^{4}$ overall total maternal post operative morbidity was $66 \%$ and majority of the complications observed were sepsis, DIC and wound infections. It is not the operation but the indication for which EPH was performed and its timing that determined postoperative morbidity. EPH was associated with extensive blood loss and need for higher number of transfusions. ${ }^{1} \mathrm{~A}$ ll patients in present study received massive blood transfusions as in other series. ${ }^{21}$

The current study al so serves as a comment on the claimed success rates of a large number of innovative techniques for controlling postpartum hemorrhage since requirement of hysterectomy can be regarded as a failure of conservative treatment. A Imost half of the women $(54.3 \%)$ required hysterectomy after uterine packing, 35\% after B-lynch suture, $3.5 \%$ after uterine artery ligation and 3.5\% after angiographic embolization. $U$ terine packing does save uteri in some cases. ${ }^{22}$ D ruzi described the preservation of reproduction potential with this technique, in case of placenta previa and accreta. Ligation of internal illiac arteries requires the service of skilled surgeons and may not be procedure of choice in the setting of massive hemorrhage and unstable patients as it may be associated with a substantial risk of failure. This is occasionally used in our unit.

\section{LIMITATIONS OF THE STUDY}

Though the present study documents the immediate morbidity associated with EPH but we could not assess the long-term psychological and medical morbidity associated with the procedure.

\section{CONCLUSION AND RECOMMENDATIONS}

This study confirms the detrimental role injudicious and liberal use of CS in the rising incidence of major placenta previa, adherent placenta and postpartum hemorrhage resulting in risk of peripartum hysterectomy. Advanced maternal age and multiparity resulting from sociocultural-religious barriers to contraception are important risk factors in this region. However, these factors could be minimized with appropriate prenatal care as well as education of pregnant women.

1. Obstetricians and the obstetric team should always be prepared to confront this emergency.

2. Presence of experienced obstetrician is important to make an early decision to operate before the patient's condition is critical to minimize the morbidity and mortality.

3. A ttempts to reduce the primary CS rate should be helpful in reducing the relative risk of hysterectomy due to morbid adherence of placenta or its abnormal location.

4. There is scope for validating the efficacy of the recent innovative therapies for control of postpartum hemorrhage in future studies.

5. EPH when performed in selected cases at an appropriate time helps in bringing down maternal mortality.

\section{REFERENCES}

1. K night M. Peripartum hysterectomy in the UK: management and outcomes of the associated hemorrhage. BJOG 2007;114:1380-1387.

2. K astner ES, Figueroa R, Garry D, M aulik D. Emergency peripartum hysterectomy: experience at a community teaching hospital. O bstet Gynecol 2002;99:971.

3. Zelop CM, Harlow BL, Ferigoletto FD J r, Safon LE, Saltzman $\mathrm{DH}$. Emergency peripartum hysterectomy. A m J Obstet Gynaecol 1993;168:1443-1448.

4. Mesleh $R, A$ youb $H, A$ Igwiser A, Kurdi A. Emergency peripartum hysterectomy. J Obstet Gynaecol 1998;18(6): 533-537

5. A faf RA, A Isayali, Salah MA, Baloul. Emergency obstetric hysterectomy: 8-years review at Taif M aternity H ospital, Saudi A rabia. A nnals of Saudi M edicine 2000;20(5-6):454-456.

6. Ozumba BC, M bagwu SC. Emergency obstetric hysterectomy in Eastern N igeria. Int Surg 1991;76(2):109-111.

7. Francois K, Ortiz J , Harris C, Foley M R, ElliottJ P. Is peripartum hysterectomy more common in multiple gestations? Obstet Gynecol 2005;105(6):1369-1372.

8. Forna F, Miles AM, Jamieson DJ. Emergency peripartum hysterectomy: a comparison of cesarean and postpartum hysterectomy. A m J Obstet Gynecol 2004;190(5):1440-1444.

9. Rabenda-Lacka K, Wilczynski J, Radoch Z, B reborowicz GH. Obstetrical hysterectomy. Ginekol Pol 2003;74:1521-1525.

10. Zorlu CG, Turan C, Işik AZ, Danişman N, M ungan T, Gökmen 0 . Emergency hysterectomy in modern obstetric practice. Changing clinical perspective in time. Acta Obstet Gynecol Scand 1998;77:186-190.

11. Rabiu KA, Akinlusi FM, Adewunmi A A, A kinola OI. Emergency peripartum hysterectomy in a tertiary hospital in Lagos, Nigeria: a five years review. Trop Doct 2010;40:1-4.

12. Tebeu PM, N dive PE, A ko WT, Biyaga PT, Fomulu JN, Doh A S. E mergency obstetric hysterectomy at U niversity Hospital, Y aoundé, Cameroon. 0020-7292/\$ - see front matter @ 2012 
International Federation of Gynecology and Obstetrics. Published by Elsevier Ireland Ltd. http://dx.doi.org/10.1016/ j.ijgo. 2012;07.013.

13. Obiechina NJA, Eleje GU, Ezebialu IU, O keke CAF, M bamara SU. Emergency peripartum hysterectomy in N newi, Nigeria: A 10 years review. Niger J Clin Pract 2012;15:168-171.

14. B akshi S, M eyer B A. Indications for and outcomes of emergency peripartum hysterectomy. A 5-year review. J Reprod M ed 2000; 45: 733-737.

15. Rahman J, Al-Ali M, Qutub HO, A I-Suleiman SS, A I-Jama FE, R ehman M S. Emergency obstetric hysterectomy in a U niversity H ospital: a 25 years review. J Obstet Gynaecol 2008;28:69-72.

16. Roopnarinesingh R, Fay L, M ckenna P. A 27 years review of obstetric hysterectomy. J Obstet Gynecol 2003;23:252-254.

17. A wan N, Bennett MJ, Walters WA. Emergency peripartum hysterectomy: a 10-years review at the Royal Hospital for women, Sydney. A ust NZJ Obstet Gynaecol 2011;51(3): 210-215.

18. Chibber R, AI-Hijji J, Fouda M M, AI-Saleh EE, Al-Adwani A R, M ohammed A T. A 26-year review of emergency peripartum hysterectomy in a tertiary teaching hospital in K uwait - years 1983-2011. M ed Princ Pract 2012;21(3):217-222.

19. Mahmood S, A yaz A. Obstetrical hysterectomy. J Surg Pak 2005; 10:20-23.

20. Korejo R, Nasir A, Y asmin H, B hutta S. Emergency obstetric hysterectomy. J Pak M ed A ssoc 2012;62(12):1323.

21. Selo-Ojeme DO, B hattacharjee P, I zuwa-N joku N F, Kadir RA. Emergency peripartum hysterectomy in a tertiary London Hospital. A rch Gynecol Obstet 2005;271:154-159.

22. D ruzin-M L. Packing of the lower uterine segment for control of post caesarean bleeding in instances of placenta previa. Surg Gynaecol Obstet 1989;169(6):543-545.

23. R oethlisberger $M$, W omastek I, Posch $M$, Hussl ein P, Pateisky $\mathrm{N}$, L ehner R. Early postpartum hysterectomy: incidence and risk factors. A cta O bstet Gynecol Scand 2010; 89(8):1040-1044.
24. Christopoulos P, H assiakos D, T sitoura A, Papadias K, V itoratos N. Obstetric hysterectomy: a review of cases over 16 years. J Obstet Gynaecol 2011;31(2):139-141.

25. Tapisiz OL, Altinbas SK, Y irci BC, Pinar KA, Ellibes DS, $\mathrm{K}$ andemir $\mathrm{O}$ Emergency peripartum hysterectomy in a tertiary hospital in A nkara, Turkey: a 5-years review. A rch Gynecol Obstet 2012;286(5):1131-1134.

\section{ABOUT THE AUTHORS}

\section{Shumaila Zia (Corresponding Authors)}

A ssistant Professor, Department of Obstetrics and Gynecology College of Medicine, King K halid University, A bha, Saudi A rabia Phone: +96-6535926658, Fax: +96-672417887, e-mail: abeeharafique@ hotmail.com

\section{Muhammad Rafique}

A ssistant Professor, Department of Pediatrics, College of M edicine K ing K halid University, A bha, Saudi A rabia

\section{Aisha Rizwan}

Specialist, Department of Obstetrics and Gynecology, A bha General Hospital, A bha, Saudi A rabia

\section{Tamkin Khan}

A ssociate Professor, Department of Obstetrics and Gynecology College of M edicine, King K halid U niversity, A bha, Saudi A rabia

\section{Ali Al-Shamrani}

Consultant, Department of Pediatric Gastroenterology, Hepatology and Nutrition, A bha General Hospital, A bha, Saudi A rabia 